\title{
УКРАЇНСЬКИЙ ПРЕФІКС ПОПО-: СПЕЦИФІКА АСПЕКТУАЛЬНОГО ЗНАЧЕННЯ
}

\author{
Ачилова О. Л. Український префікс попо-: специфіка аспектуального значення. \\ Стаття присвячена дослідженню специфіки аспектуального значення дієслів з оригінальним \\ українським префіксом попо-. Встановлено особливості перекладу таких дієслів російською мовою. \\ Ключові слова: семантичний компонент, багатократність, тривалість, інтенсивність. \\ Ачилова Е.Л. Украинский префикс попо-: специфика аспектуального значения. \\ Статья посвящена исследованию специфики аспектуального значения глаголов с оригинальным \\ украинским префиксом попо-. Выявлены особенности перевода таких глаголов на русский язык. \\ Ключевые слова: семантический компонент, многократность, длительность, интенсивность. \\ Achylova O. Ukrainian prefix попо-: the specification of aspectual meaning. \\ The article is devoted to investigation of specification of aspectual meaning of verbs with original \\ Ukrainian prefiх попо-. The features of the translation of such verbs in Russian are revealed. \\ Key words: component of semantic, frequentative, duration, intensity.
}

Аспектуальні значення приєднуються до значення дієслівних лексем i реалізуються в загальнодісслівній категорії аспектуальності та іiі субкатегоріях: виду й родів дієслівної дії (РДД). За допомогою категорії виду в слов'янських мовах виражаються «такі семантичні ознаки, як часова локалізація, динамічність / статичність, кратність, тривалість, моментальність, узуальність, початковість, результативність і под.» [1, c. 11].

Під час визначення семантичних елементів, які складають видові значення, традиційно вважають, що дієслівні форми доконаного виду (ДВ) можуть передавати семантику результативності, лімітативності й моментальності, а форми недоконаного виду (НДВ) - семантику протяжності і повторюваності [10, с. 28-29]. Варто зазначити важливість цього факту, тому що в українській мові існує досить продуктивна словотвірна модель дієслів НДВ з багатократним, тривалим або інтенсивним значенням. Йдеться про дієслівні утворення 3 подвійним префіксом попо-.

В. М. Русанівський вважав дієслова 3 подвійним префіксом попоодним 3 найоригінальніших утворень у системі родів дієслівної дії української мови [9, с. 517]. Таку думку підтримують також інші науковці: «Специфікою дієслівної словотвірної підсистеми української мови, іiі національно-самобутньою рисою $\epsilon$ утворення й функціонування аспектуалізованого «попо» [11, с. 113].

Метою цієї статті $є$ аналіз аспектуальної семантики українських дієслівних утворень 3 префіксом попо-. Джерелом дослідження стали твори українських письменників XIX-XX століття.

Актуальність цієї розвідки зумовлена необхідністю дослідження особливостей аспектуальної семантики українських дієслівних форм 3 
редуплікованим префіксом попо- i можливостей їхнього адекватного перекладу.

Наукова новизна статті полягає в дослідженні функціонування дієслів з попо- в умовах перекладеного тексту.

Методика і матеріал: у роботі використано метод суцільної вибірки зі словника, компонентний аналіз словникових тлумачень, зіставлення оригінальних текстів художніх творів українських авторів М. Коцюбинського, У. Самчука, В. Симоненка, Марка Вовчка 3 їх російськими перекладами, а також наші спроби адекватного перекладу. У зв'язку із суб'єктивним авторським підходом до складання словникових статей, питання потребує додаткового дослідження.

3 погляду морфології префікс попо- - це явище послідовної, повної і чистої редуплікації [3, с. 43-44]. Як відомо, редуплікація префікса може призвести до виникнення нових префіксів, значення яких відрізнятимуться від значень одинарних префіксів.

Л. І. Ройзензон вважає, що «кількість двопрефіксних дієслів у сучасних слов'янських мовах порівняно 3 їхніми давніми складами біплексів збільшилося» [3, с. 20]. Відзначимо, що в «Словаре украинскаго языка» під редакцією Б. Грінченка, датованому 1909 р., зафіксовано 77 утворень 3 префіксом попо-, а в «Словнику української мови» 1976 р. їх уже понад 100 [4].

Дієслова 3 таким префіксом зараховують до делімітативноінтенсивного РДД i, як уже зазначалося, виражають тривалу, інтенсивну або багатократну дію, що відбувається протягом певного часового відрізка, наприклад: попоходити, попоносити, попоїзити, поподумати, попобити і т. ін. [7, с. 66-67]. Крім того, ці дієслова завжди позначають дії, здійснювані істотами, переважно людьми.

Специфіка аспектуального значення таких дієслів зумовлена тим, що вони є формами ДВ, які здатні виражати багатократне (ітеративне) або тривале значення. На думку А. Тимберлейка, «ситуація не може бути позначена дієсловом ДВ, якщо вона (1) тривала або (2) множинна (з високим ступенем кратності)» [8, с. 273]. Як видно, наявність дієслівних утворень $з$ префіксом попо- нівелює наведене вище зауваження для системи українського дієслова. Крім того, не можна забувати про дієслова 3 дистрибутивним значенням, які також характеризуються семантичною ознакою повторюваності (для всіх слов'янських мов).

Отже, значення ітеративної закінченої дії, що його вносить редуплікований префікс, «пов'язане 3 перфективністю дієслів, тоді як в інших слов'янських мовах, наприклад, у польській, російській і чеській ітеративність пов'язана з імперфективністю: chadzac', mawiac'; хажсивать, говаривать. Іншими словами, попо-дієслова - це ітеративні дієслова доконаного виду» [11, с. 113]. Наприклад: $A$ Леонід туm поповиглядав тебе з Васильком (у значенні видивлявся, виглядав багато разів) [5, с. 213]. 
Проте діапазон значення дієслів з подвійним попо- не обмежується повторюваністю. Більш того, важливими елементами семантики таких дієслів є тривалість і достатність, інтенсивність: «Повторенням префікса по- відтінок тривалості дії посилюється, супроводжуючись означенням достатності; такі утворення завжди мають розмовний характер: Уже $і$ так пополякали» (у значенні довго лякали і дуже налякали) [2, с. 137].

Результати компонентного аналізу наведені в таблиці.

Проведене нами дослідження показало, що в деяких дієсловах 3 префіксом попо- перетинаються три зазначені семантичні компоненти, у деяких - два, у деяких виявляється один семантичний компонент. Привертає увагу й той факт, що декілька лексико-семантичних варіантів (ЛСВ) дієслів 3 попо- характеризуються як нейтральні щодо семантики повторюваності, тривалості й інтенсивності. Див. таблицю.

\section{Дісслово / \\ Диференційні ознаки}

Багаторазовість

Тривалість

Інтенсивність

Попогуляти

Пополупити

Попоплакати

Попосміятися

Попоходити

Попоблукати

Поповарити

Поповештатися

Поповиглядати

Попоговорити

Поповозитися

Поповчити

Попоганяти

Попогорювати

Поподивуватися

Попобачити

Попобити 1

Поповажити

Поповикидати

Пополамати 2

Попогребти

Попогриміти

Поподихати

Попождати

Попожити

Попобити 2

Попобитися

Попоїсти 3

Попопрати 2

Попоїсти 1

Попоїсти 2

Попопити

\begin{tabular}{|c|c|c|}
\hline$t$ & + & + \\
\hline+ & + & + \\
\hline+ & + & + \\
\hline+ & + & + \\
\hline+ & + & + \\
\hline+ & + & - \\
\hline+ & + & - \\
\hline+ & + & - \\
\hline+ & + & - \\
\hline+ & + & - \\
\hline- & + & + \\
\hline- & + & + \\
\hline & + & + \\
\hline & + & + \\
\hline & + & + \\
\hline+ & - & - \\
\hline+ & - & - \\
\hline+ & - & - \\
\hline+ & - & - \\
\hline+ & - & - \\
\hline & + & - \\
\hline & + & - \\
\hline & + & - \\
\hline & + & - \\
\hline & + & - \\
\hline & - & + \\
\hline & - & + \\
\hline & - & + \\
\hline & - & + \\
\hline & - & - \\
\hline & - & - \\
\hline & - & - \\
\hline
\end{tabular}


Відзначимо, що серед дієслівних утворень 3 префіксом попо- немає жодного, який можна було б схарактеризувати лише як сукупність сем повторюваності й інтенсивності (без семи тривалості). Отже, тривалість $\epsilon$ головною диференційною семантичною ознакою українських дієслів 3 попо-. Цей факт підтверджується й тим, що семантика тривалості виявляється в 118 дієслівних формах, повторюваності - в 60, інтенсивності - в 47 (із 136).

В. М. Русанівський пропонує розрізняти значення префікса по-, що приєднується до дієслів 3 таким префіксом, і значення редуплікованого префікса попо-. На думку лінгвіста, в українській мові префікс по- може передавати значення обмеженості дії в часі: сидіти - посидіти (сидеть посидеть), лежати - полежати (лежать - полежать), праџювати попрацювати (работать - поработать) тощо. «Це значення він зберігає й у деяких дієсловах, що вже мають у своїй структурі префікс по- 3 фінітивним значенням: бити $\rightarrow$ побити $\rightarrow$ попобити (бити якийсь час), їсти $\rightarrow$ поїсти $\rightarrow$ попоїсти ... і под.» [6, с. 270]. На відміну від по-, що приєднується до префіксальних дієслів 3 іншими префіксами, редуплікований префікс попо- має єдину семантику. «Дієслова 3 цим префіксом мотивуються безпрефіксними дієсловами і передають результат інтенсивно й неодноразово виконуваної (ітеративної) дії: поповештатися $\leftarrow$ вештатися, поповозити $\leftarrow$ возити, поповодити $\leftarrow$ водити ... тощо [6, с. 270].

Автор тлумачить лексему попобити лише як дію, обмежену в часі, що, ймовірно, зумовлене наявністю семи інтенсивності вже в мотиватора. На наш погляд, наявність даної семантичної ознаки не суперечить значенню повторюваності, вираженому цією лексемою. Таку інтерпретацію дієслова попобити подає й словник: Попобити 1. Бити багато разів кого-небудь. 2. Дуже побити [5, с. 212]. Що ж до значення дієслова попоїсти, то воно справді означає те саме, що й наїстися // поїсти чого-небудь [5, с. 216]. Особливо наголосимо, що значення ітеративності, тривалості й інтенсивності зберігається у разі функціонування дієслів з префіксом попо- у складі ідіоматичних одиниць. Так, голову пополамати означає інтенсивно думати тривалий час, вирішуючи будь-що; попоміряти вздовж $i$ впоперек що-небудь означає ходити багато разів якою-небудь місцевістю; попом'яти боки кому-небудь означає дуже побити кого-небудь тощо [5, с. 217-219].

Характерною особливістю українських дієслів 3 префіксом попо- $\epsilon$ стилістична маркованість і вживаність винятково в розмовному мовленні або в мові художньої літератури. Підкреслимо, що слов'янська дієслівна поліпрефіксація є одним із засобів посилення експресивних можливостей слов'янського дієслова. Ці дієслова настільки самобутні, що не можуть бути точно перекладені іншими (навіть спорідненими) мовами за допомогою аналогічних багатопрефіксальних дієслів. Як справедливо 
зауважує С.О. Соколова, значення українських дієслів делімітативноінтенсивного РДД можливо передати російською мовою шляхом поєднання дієслів делімітативного РДД 3 лексичними показниками $[7$, с. 67].

Розглянемо, яким чином реалізують своє аспектуальне значення українські дієслова з префіксом попо- в структурі художніх творів:

Андрій намагався обернути все в жарт.

- Не скигли, стара, сідай та попоӥэс рибки. Нема м'яса, як свинина, нема риби, як... (М. Коцюбинський).

Наводимо переклад М. Ушакова:

Андрей старался всё обратить в шутку.

- Не скули, старуха, садись да поешь рыбки. Нет мяса лучше свинины, нет рыбыл лучше, чем...

Ще фрагмент:

А Маланка лютувала. Опріч того, щзо ї̈ живий жаль брав за знівеченою рибою, вона була голодна. Вона захляла з голоду, їй так хотілось чогось гарячого, смачного, незвичайного, а дух свіжої линини лоскотав ніздрі, спирав віддих; їй аж нудило од сильного бажання попоїсти (М. Коцюбинський). - А Маланка бушевала. Кроме того, что она горевала об испорченной рыбе, она была голодна. Она ослабела от голода, ей так хотелось чего-нибудь горячего, вкусного, необыкновенного, а запах свежего линя щуекотал ноздри, перехватывал дыхание; её даже тошнило от сильного желания поесть.

У наведених фрагментах тексту поліпрефіксальне дієслово попоїсти реализує своє перше значення, яке російською мовою адекватно передає дієслово поесть. Розглянемо інші ілюстрації:

Збирали пізні гречки, коли в селі несподівано з'явився Гущза. Його не зразу впізнали. Він обріс бородою, став стариий $і$ наче трохи чужий. Гушу прийняли добре <...>

- Що, попосидів?

- Мовляв, знаєм, за щзо.

Якось інакше, ніж перше, люди говорили слово «попосидів в тюрмі, більше знає, ніж ми» (М. Коцюбинський).

Проаналізуємо переклад:

Убирали позднюю гречиху, когда в деревне неожиданно появился Гущца. Его не сразу узнали. Он оброс бородой, стал старше и казался каким-то чужим. Гущу приняли хорошо <...

- Что, отсидел?

Мол, знаем, за что.

Как-то иначе, не так, как прежде, мужики говорили:

- Отсидел в тюрьме, больше нас знает.

Цей фрагмент тексту перекладено не зовсім точно. У словнику зафіксовано таке тлумачення ЛСВ попосидіти: 4. Бути ув'язненим 
тривалий час [5, с. 220]. Як видно, під час перекладу утрачено сему тривалості дії. Дієслівна форма отсидел выражає фінітивну фазу дії, яка закінчилася, що в українській мові передає грамема відсидіти.

Порівняємо ще фрагмент:

Провела його за село, того чоловіка, попоплакала... Минуло з тиждень (Марко Вовчок). - Проводила я этого человека за село, поплакала. Прошло с неделю.

Дієслівна форма попоплакати поєднує в собі значення багатократності, тривалості й інтенсивності. У перекладі (автора перекладу не вказано) актуалізоване лише значення тривалості. На нашу думку, варіанти поплакала, долго плакала (із семантикою тривалості) або наплакалась (із семантикою інтенсивності) не можуть повною мірою реалізувати всі аспектуальні відтінки українського дієслова попоплакати.

Спробуємо перекласти російською мовою фрагменти текстів, які раніше не перекладалися:

Вона грайливо перекинула коси зі спини на груди.

- Я хочу, щуоб хтось полюбив мене, а не мою красу, чорні брови та рожеві щуічки. - Вона помітила, щуо Андрій хоче вклинцювати своє слово, $i$ заговорила ще швидше: - Що та краса? Вітри видублять шкіру, дощі змиють рум'янецьь! Натягаєшся ящчиків на токах, попогнеш спину на буряках - де та й врода дінеться...(В. Симоненко).

Она игриво перекинула косы из-за спины на грудь.

- Я хочу, чтобы кто-нибудь полюбил меня, а не мою красоту, чёрные брови и розовые щзёчки. - Она заметила, что Андрей хочет вставить своё слово, и заговорила ещеё быстрее: - Что от этой красотьл? Ветры выдубят кожу, дожди смоют румянец! Натаскаешься ящиков на токах, хорошенько погнёшь спину на свёкле - куда и денется эта красота ...

Дієслово попогнеш выражає багатократну, тривалу дію, яку російською мовою можна передати лексемою НДВ погнёшь 3 лексичним показником хорошенько, що дасть змогу підкреслити зазначену семантику в поєднанні з експресивною інтенсивністю. За рахунок поєднання лексем попогнеш и натягаєшся це значення посилюється на рівні всього контексту.

От уже інша сторія з Василем. Чей же до иколи лазить; ніяково, щзоб дитина темною залишилася, а тутка $i$ школа. Бог відає, де. Попотьомбай-но щцодня милю туди та милю назад (У. Самчук). - Вот уже другая история с Василием. Этот уже в иколу лазит; неудобно, чтобы ребёнок тёмным оставался, а туточки и икола. Бог знает, где. Потопай-ка каждый день милю туда и милю назад.

Дієслово тьомбати є діалектизмом і не зафіксоване в словниках літературної мови. Тлумачити його можна як ітеративну дію, посилену наявністю редуплікованого префікса попо- й лексичного показника 
регулярності щздня. Точно передати російською мовою експресивноінтенсивну повторюваність цієї дії нам видається складним навіть за допомогою лексичного детермінанта.

- Де то ти так довго барився? - питає батько. Захлинаючись, Володько, n'яте через десяте, оповідає, що то за страшне те коровисько $i$ скільки-то воно його попомучить...(У. Самчук). - Где это ты так надолго задержался? - спрашивает отец. Захлёбываясь, Володька, с пятого на десятое, рассказывает, какая страшная эта коровища и как долго она его ещё будет мучить...

Дієслівна форма попомучить реалізує значення тривалої інтенсивної дії в аспекті майбутнього часу (хорошенько, сильно помучает), посилене лексичним показником тривалості скільки то. У перекладеному варіанті семантичний елемент «інтенсивність» втрачається.

Ми вже згадували про дієслово попоїсти, у значенні якого відсутні такі семантичні елементи, як повторюваність, тривалість і інтенсивність. Проте за певних контекстуальних умов семи повторюваності й інтенсивності актуалізуються й домінують над значенням обмеженості дії в часі. У наведеній нижче ілюстрації ці семантичні елементи посилені наявністю емоційно-експресивних лексем угодую й салиська:

- Як угодую картоплею веприка - попоїси салиська. А з собаки що? Сморід та блохи (У. Самчук, с. 241).

Переклад:

- Как откормлю картошкой кабанчика - вдоволь поешь салища. А с собаки что? Вонь да блохи.

Цікаво, що в російському варіанті на перший план значення дієслівної форми виступає сема накопичувальності.

Отже, українські дієслова 3 редуплікованим префіксом попо- $\epsilon$ оригінальними утвореннями з погляду реалізованого ними аспектуального значення. Специфіка аспектуального значення таких лексичних одиниць полягає в тому, що форми ДВ 3 характерним для них значенням закінченості дії набувають семантичних ознак інтенсивності, тривалості й повторюваності, які не властиві для інших форм ДВ. Враховуючи таку їхню особливість, для адекватної передачі семантики дієслівних форм 3 префіксом попо- російською мовою необхідно залучати лексичні детермінанти.

\section{Література}

1. Зализняк А. А., Шмелёв А. Д. Введение в русскую аспектологию / А. А. Зализняк, А. Д. Шмелев. - М. : Языки русской культуры, 2000. - 226 с.

2. Ільїн В. С. Префікси в сучасній українській мові / В. С. Ільїн. - К., 1953. - 167 с.

3. Ройзензон Л. И. Славянская глагольная префиксация : автореф. дисс. докт. філол. наук Л. И. Ройзензон. - Минск, 1970. - 103 с.

4. Словарь української мови. - К., 1909. - Том III. - 507 с.

5. Словник української мови. - К. : Наукова думка, 1976. - Том VII. - 724 с.

6. Словотвір сучасної української літературної мови. - К. : Наукова думка, 1979. - 407 с.

7. Соколова С. Аспектуальні категорії українського дієслова на тлі інших слов'янських мов / С. Соколова // Українська мова. - 2003. - №2 (7). - С. 61-70. 
8. Тимберлейк А. Инвариантность и синтаксические свойства вида в русском языке / А. Тимберлейк // Новое в зарубежной лингвистике - Вып. XV : Современная зарубежная лингвистика. М. : Прогресс, 1985. - С. 261-286.

9. Українська мова: [енциклопедія]. - К. : Українська енциклопедія, 2000. - 752 с.

10. Черткова М. Ю. Грамматическая категория вида в современном русском языке / М. Ю. Черткова. - М. : Изд-во МГУ, 1996. - 172 с.

11. Wieczorek D. Украинский язык. Slavia Romana - Slavia Byzantina. Очерки по глагольности / D. Wieczorek. - Wrocław : Wydawnictwo Uniwersytetu Wrocławskiego, 1998. - 135 c.

\section{Джерела}

Вовчок Марко. Избранное : [рассказы, повести, сказки] / Марко Вовчок. - М. : Худ. лит., 1976. - 590 с. Вовчок Марко. Твори в 6-ти т. / Марко Вовчок - К. : Держлітвидав., 1955. - Т. 1. - 400 с.

Коцюбинський М. Вибрані твори / М. Коцюбинський. - К. : Дніпро, 1974. - 512 с.

Коцюбинский М. Повести и рассказы / М. Коцюбинский. - М., 1953. - 800 с.

Самчук У. Марія. Куди тече річка / У. Самчук. - К. : Наук. думка, 1999. - 416 с.

Симоненко В. Берег чекань / В. Симоненко. - К. : Наукова думка, 2001. - 248 с. 